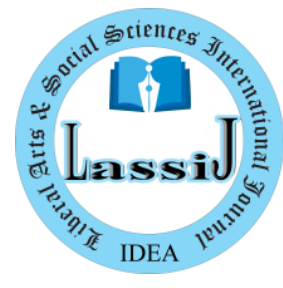

Research Article

ISSN: 2664-8148 (Online)

Liberal Arts and Social Sciences

International Journal (LASSIJ)

https://doi.org/10.47264/idea.lassij/3.2.1

Vol. 3, No. 2, (July-December) 2019, 1-10

https://www.ideapublishers.org/lassij

\title{
Political Instability in Sudan after Military Coup: Implications for China's Economic Interests
}

\author{
Nazim Rahim*1, Assad Mehmood ${ }^{1}$ and Syed Mussawar Hussain Bukhari ${ }^{2}$
}

1. Department of Political Science and International Relations, Qurtuba University of Science and Information Technology, Peshawar Pakistan.

2. Department of Political Science and Gender Studies, Islamia University of Bahawalpur, Pakistan.

Received: August 6, 2019

Published Online: December 11, 2019

\begin{abstract}
The current military coup and further political unrest in Sudan, though termed as 'Bread Riots,' however the internationally observed, beyond 'bread.' Especially, the Darfur and Sudan's current crisis vis-à-vis China's increasing politico-economic engagement in pursuance of its interests in the Sudan, particularly about energy sector, have placed China's policies for Africa in focus. Since, Sino-Sudan maintained an extended history of politico-economic engagement and outreaching diplomatic relationships, hence, internationally perceived an expectation that Chinese factor can persuade the politico-economic situation in Sudan after recent political unrest in the country. Considering, such conditions, this paper while employing the economic diplomacy theory argues that, the policy of 'non-interference' may not be translated as disinclination with regards to China to employ the conscientiousness to defend. In this paper, statements given by the world about the interests lie in Sudan have been analysed through content analysis technique. However, particularly the complex features of condition of instability in Sudan, the economic-engagement strategy pursued by China, seems much productive than the retaliatory sanctions initiatives being approached by the West, particularly US to ensure peace process and stability conditions in Sudan. China had deep concerns with the situation prevailing in Sudan because it has invested billions of dollars on the development projects in this country.
\end{abstract}

Keywords: China, Sudan, Darfur, Economic Engagement, Political Instability, BRI, UN

\section{Introduction}

Sudan's unrelenting dominance of the central power at Khartoum over the ignoble regions like Darfur and Kordofan, locales determining intense provincial disparities (Brosché, 2008). Hence, prevailing power sharing disparities along-with socio-political and socio-economic stand-off has been often referred as major cause for the conflicts, leading major unrest in Sudan (Shay, 2005). Therefore, many ethnic groups along-with public and professional segments of the society demanded for a long awaited change in politico-economic spheres of the state and also being witnessed by the international community during recent crisis and demonstrations in Sudan (VOA, 2019). The existing crises in the state are an outcome of civilian prolonged protest on the roads of capital city. Though, it started from peripheral domains to centre of 
power in Khartoum, which has outreaching fall-outs internally on Sudan's politico-economic conditions and externally on international community as whole and China in particular (Omer, 2018). This research article endeavours to contextualize causes of instability in Sudan and its implications for global economic engagement challenges, particularly China's engagement in Sudan. The foremost goal of this article is to help succinct understanding of politico-economic instability reasons in Sudan and its implications for overall economic engagements including China. Furthermore, this research will help the academia and researchers in this issue.

\section{Literature Review}

The Sudan's armed forces overthrew sitting head of state Omar al-Bashir after a visible coup d'état on $11^{\text {th }}$ April 2019 (BBC, 2019), subsequent to months prolonged protest against the public offices in capital and long-holding authoritarian. The recent emergency and instability crisis were caused because of the protest derived by the professional cadre of the society including doctors, engineers, lawyers and other professionals, women organizations, under a combined banner named the 'Sudanese Professionals' Association' (Goldstein, 2019). Mainly, the protest started in December last year (2018), complaining against the rise of 'bread' and livelihood costs in the state, organized demonstrations, protest rallies, initially in peripheral regions and later culminating at Khartoum after a sit-in on the streets of capital. Endured demonstrations and sit-in on the roads of capital emerged as pointed change in the country which had no precedence under the authoritative regime of Omar al-Bashir during last thirty years (Burke, 2019). The recent protests are characterized by the leadership of energetic professionals of all academia throughout the state (Lynch, Gramer, Lynch, \& O'donnell, 2019).

Though, the successive demonstrations by these professionals started in capital city and major regions of Sudan, particularly because of escalating costs of livelihoods and worsening politico-economic affairs throughout the societal levels. However, the demonstrators rapidly twisted from simple petitions in support of immediate financial reorganization in system to resignation of Omar al-Bashir, the president. Moreover, owing to the situation, government authorities reacted with force, causing damages and causalities to the peaceful demonstrators, resultantly, asked for worldwide apprehensions on the situation. On February 22, 2019, Omar al-Bashir, announced emergency in the country, hence, suspended the central and provincial assemblies, placed orders with armed forces and intelligence-services offices (BBC, 2019). Apprehending the situation, March 8, 2019 was marked as release day for detainee women of the demonstrations, hence provided new energy to the protest (Reuters, 2019). Though, the declaration of emergency curtailed the demonstrations, however, could not banned from a massive demonstration against the government during first week of April, since the imposition of emergency. On April 10, 2019 the equipped armed forces were observed shelling against the demonstrators, resulted in aggression (Shakeel, 2019). Following day observed a change of the authoritative regime in the country, the president, Omar al-Bashir, was sacked from command in a military lead coup d'état (CNN, 2019). Though, the removal of Omar al-Bashir, filled the demands of protestors, however, the demonstration continued, as the demonstrators along-with the opposition political affiliates, engaged in sit-in and rallies on the roads of capital, launched demand of immediate and unconditional withdrawal of military council in support of civilian-led intermediary supervision, leading process of political transition and transformation of economic reforms in the state of Sudan.

Sino-Sudan's close relations date back to Sudan's freedom, recognized by China as forth state 
of Africa in1959 (Larkin, 1973). Ever since, the decade of seventies, marked by China's politico-economic provisions and engagements in Sudan, including grants, interest-less easy loans and technological support (Bramall, 2008). The relationship was enhanced in Nimeiri's regime in Sudan, during the era of Cold-War (Large, 2009). Presently, China's politicoeconomic engagement character in Sudan is mainly that started with oil exploration; characterized by further dynamic challenges of recent developments (Currier \& Dorraj, 2011). Moreover, China's engagement in Sudan is commonly acknowledged as vital to Khartoum's politico-economic expansions and diplomatic relationships, and presently, China's African policies are accepted on many platforms and are relatively more complicated, multi-dimensional, and determined, thus necessitating larger possibilities (Coning, Aoi, \& Karlsrud, 2017).

China's factor in Sudan, now forms element of generally changed and still growing engagements by Chinese in African continent and the world as whole especially through the One Belt One Road (OBOR) project (Rehman, Hakim, Khan \& Khan, 2018; Khatoon, Rahim, Ali, 2018). China's dynamic diplomatic focus over Darfur has not merely globalized China's existence in Sudan however listed other Asian states for their existence in Sudan (Woodward, 2013). Reportedly, the Sudan's exports by Asian-states were 21.9 percentages in year 1994, grew up to 85 percentages in year 2005-06, while remained US dollar 803,090.14 with 18.94 percentages share of Asian-states' partner in year 2017 (WB, 2017). Moreover, China dominates as the leading crude-oil buyer of Sudan and also the major overseas shareholder (Patey, 2011). Presently, the African states supply over a quarter of Chinese requirements for crude-oil sources (Powanga \& Reichl, 2019). Moreover, China's 'good-governance', such support of politico-economic engagement has strengthened in Sudan (Maglad, 2007). Hence, the Chinese caught the opportunity of being offered to discover oil-capital resources potential of Sudan, emerged as launchpad for China in Africa (Brautigam, 2011). Chinese acquired around eighty percentages of Sudan's crude-oil throughout the years 2001-04 and reached up to US dollar 405.17 million in 2017 with manageable ups and downs (API, 2018). Currently, China is the major imports and exports collaborator along-with UAE and Saudi Arabia.

\section{Methods and Material}

This study is qualitative in nature. This is a descriptive analytical work which has intentions to describe the situation prevailing in Sudan and its impacts on China's economic interests. After describing the whole scenario of political instability in Sudan, this work analyses the opportunities and problems for China. Secondary data has been used in this study while primary data is also consulted in form of government policies, statements of official etc. The focus of this study is economy of Sudan after current military coup therefore the already set numbers about economy and trade are also used. The gathered data is analysed while using content analysis technique.

\section{Discussion and Findings}

The relations between China and Sudan were established in 1959, when Sudan recognized the Communist China. Sudan was the first ever country in Sub-Sahara Africa which established official relations with China after a communist revolution. The relations which were established in the late 1950s, now have become strong as China is the largest investor in Sudan. Sudan remained under immense and strict economic sanctions since 1995, put by United States because of earlier relations between the Sudan's government and Al-Qaeda. In these days 
China is enjoying exceptional relations with Sudan. It is difficult to find out American consumer stuff from the markets of Sudan except worldwide known brands e.g. Coca Cola. The relations between Sudan and China in the field of oil started from the same year of 1995 when US put sanctions on Sudan.

\subsection{China's Economic Activities in Sudan}

Sudan's recent politico-economic crisis might be traced back and linked with the separation of South Sudan in year 2011, which actually directed to the deficit of virtually around threefourth of its oil-capital assets (LeRiche \& Arnold, 2013). Earlier, the oil-capital engendered roughly half of overall tax returns and two-thirds of its overseas market income. Following, the influence of economic distress of division was unavoidable; Khartoum too was unprepared for fallouts. However, long-standing politico-economic misconduct, enveloping embedded high armed forces spending as supported to unreasonable levels of expenditures, moreover, worldwide seclusion caused owing to the sanctions imposed by US, also added into the burden. More recently, the ruling government undervalued the local currency, reaching from seven to thirty pounds per US dollar up to 2108 (AFP, 2018). Subsequently, the initial devaluation since 2018, coupled with illegitimate corresponding market-rates, the ruling-party then became troubled concerning the possibilities of uncontainable hyperinflation. Even in late 2018, the official value maintained at $68.93 \%$, the highest in the international ranking of the times and recorded 44.29\% in February 2019 (API, 2018). Moreover, the government circumscribed efforts resulted unsuccessful to deal with the politico-economic crisis, and fuelled dissatisfaction, hence gradually ended up to the latest situations in the country.

Though, in latest recount, Sudan affirmed greatly on economic support of Gulf collaborators, predominantly the UAE, Qatar and Saudi Arabia's assistance, to uphold its severely falling economic condition; hence reported by the International Monetary Fund (IMF), an anticipated US\$ 2.5 billion deposits in Sudan's central bank during 2016-17, by Gulf Kingdoms (IMF, 2017). However, China's politico-economic engagement with Khartoum in in the backdrop of Darfur crisis. More specifically the recent unrest and current military coup, political instability and economic decrease in Sudan has vital effects on the overall relationship. Broadly, it has been harmonizing with the refoulement of political environments with a more natural capital oriented economic persuade motivating China's contemporary relationships with Africa in general and Sudan in particular. China's investments are not exaggerated by the conventional considerations of menace till now, even the internal or the external players. China makes available gain in open market if not measured incredibly uncertain or not to beneficial. China remained one of the major business and industries collaborators, yet the third leading trade and industry associate with China within Africa during year 2004-05, following South Africa along-with Angola on the continent. Moreover, China is termed as the main overseas collaborator from the Sudan's perspective; hence it has share of around $0.2 \%$ to $0.3 \%$ in China's overall overseas businesses (API, 2018).

Moreover, Sudan's FDI course was maintained US\$ 1.1 billion and mainly based on China's investments in crude-oil capital (UNCTAD, 2018). Today, Sudan's imports from China are influenced by technology and apparatus, manufactured supplies, transportation sources, clothing, and compounds. However, Sudan's imports were maintained at US\$ 942.0 million in 2018, amid average of US\$ 707.3 million yearly from 2003-2018 (CEIC, 2018). 
Furthermore, demands in Sudan are originated by escalating production activities. Additionally, there are increased exports of automatic as well as electronic supplies to Sudan. Sudan's exports were maintained US\$ 385.9 million in 2018, amid average of US\$ of 385.8 million yearly from 2003-2018 (CEIC, 2018). Moreover, following zero-tariff exports outline to Sudan, it may enhance more speedily. China must improve the road and rail network of the state; hence the Chinese corporations are presuming a bigger responsibility in the farming, mining, medication, and edification segments for over last decade and so.

Besides, industrial development projects, employment of country owned labour is also a dominating factor, that on one side assists skilled development and on other side extended labour restrictions on the corporations in the field, hence contributing on one side and resulting poverty to local labour on other side. The numbers of Chinese staff in the different ventures, underway in Sudan is not below to 100,000 individuals. The character of these labour is more than closely controlled presenting the sense to a few that it ought to be formerly from a structured organization; contrasting in the1907s, while the Chinese offered training to the Sudanese and moved back, but current labour is incredibly devoted to stay in Sudan. SinoSudan economic engagements were raised during 2017, while noticeably with increased business (World Bank, 2019). Crude-oil and ordinary-gas have constantly had, furthermore will maintain to have enduring geo-political and geo-economical scope. By means of minor exemptions, crude oil capital and ordinary-gas assets, are vital to the manufacturing industries and the majority of it is situated in the geo-areas those are not manufacturing industries, mostly topographically inaccessible and politically instable. Therefore, the energy along with diplomatic relations has conventionally been exaggerated by one-another.

In varying degrees of predominance from state to state, Chinese existing or subsequent position has significant geo-strategic, geo-political and geo-economic scope, for them as well as in the international order. From late eighties, China has experienced continuing and elemental transformations, concerning its domestic as well as the global politico-economic strategies and diplomatic policies. The centre of China's attention in Sudan, along with African continent more largely, is crude-oil capital. Whereas China anticipated its industrialization expansion to reach ever-increasing demands for energy, hence, by end 1990's China's crude-oil sources, before now exceeded their productions (Lai, 2007). Following, the quest to explore new energy sectors, Sudan particularly appeared more attractive to China, since western investors had introverted Sudan, owing to politico-strategic goals along with safety and security issues. Today, China's progress is to assume from where the leaving players left, hence introduced own engagement policy which is advantageous to manifolds.

Chinese oil-field corporations seize the foremost supplies in Sudan' soil-fields, as Ibrahim, the minister for foreign affairs stated: "China's foremost investment started in Sudan; began with oil trade however, now exploring trades, mining, as well as the constructions (Hammond, 2017). These oil-field corporations secure around forty percentages shares in the 'Greater-Nile Petroleum Operation Company' (GNPOC), recognized in Sudan since 1997 (GNPOC, 2019). Similarly, the 'China's National Petroleum Corporation' (CNPC) possess $41 \%$ shares, recognized in Sudan since 2001 (Hammond, 2017), while, SINOPEC, possess an added 6\% of petro-productions. During 2007, besides mentioned, the CNPC to enter into a petroproductions sharing contract with Sudanese government to survey an off-shore sector, around 1.6 kilometres channel was developed that connected Sudan's oil-fields to world wide openmarkets (Tu, 2008). China's oil-field corporations have too much contributed in other energy 
correlated ventures including hydro-power projects and electro-power plants. Although, the 'Comprehensive Peace Agreement' (CPA) of 2005, shelters the presented agreements form consultations and enables South-Sudan to $50 \%$ of the entire crude-oil capital productions within southern regions, however, there are accusations on Khartoum for under-counting crude-oil capital productions.

Sino-Sudan military relationship persists continuously and might yet be growing in years to set-in. regularly, the meetings among China and Sudan armed forces leadership have been a feature covering years of 2002, 2003, 2005 and 2007 (Manyok, 2016). Armed warplanes remained significant feature of transportation to Sudan's military by China, covering years of 1990s. Armament categories included: Military hardware listed in an inventory of armed forces firing weaponries, armed guns, assembly parts of martial armaments; non-military hardware's listed in an inventory of firearms, sports and hunting shotguns along-with assembly parts of these weapons; small-arms and light-weapon's ammo listed in an inventory of shot guns' cartridges and small- arms' ammos. However, China noticeably affirms its assistance to the 'Comprehensive Peace Agreement' (CPA), moreover, contributing forces for UN peace mission in Darfur, region of Sudan, since 2000 (Gill \& Huang, 2009). Furthermore, another transformation can be observed in the reality that Beijing is overtly accepting the responsibilities to avert arms transformations in Darfuric-region of Sudan.

Since 2002, Sino-Sudan armed forces relationship has progressively augmented; commencing with military leadership delegation in March 2002 to high-level conferences arranged consecutively in 2003, 2005 and 2007s (Manyok, 2016). Unquestionably, such military collaborations too have energized the arms trades, which have currently increase data fast pace. However, these delegations, high-level conferences and contracts too have implications with regards to the crisis in Darfur and instability in the Sudan at large. China's weapons trade and supplies increased up to twenty-five times during 2002 to 2005, though much of it happened under UNSC's arms sanctions; its resolution 1556 of 2004, proscribed the entire states as of engagement in the weapons trade and supplies within Darfur region (Taylor \& $\mathrm{Wu}, 2013$ ). However, noticeably important that country-to-country transportation starting one region to Sudan's capital is not proscribed under such resolution, therefore, it is tremendously complex to display infringements; [since Chinese have yet accepted that it has a consideration to avoid its armaments from getting into Darfur] (Ahmed, 2010).

China's aid-support often maintains infrastructural developments so as to expand natural capital resources right of entry; hence aid programs are featured by linked acquisitions of Chinese manufactured items along-with provision of services; and no-strings annexed a technique that constructs diplomatic influences, particularly in in-accessible states similar to Sudan. Year 2007, observed China's announcement of dispatching around five consignments of human-assistance aid-packages for Darfur (Herman, 2014). These consignments of human-assistance aid-packages incorporated pump-machineries, vehiculartransportations, collapsible-shelters, medics and health care facilities and agricultural instrumentalities. All consignments of human-assistance aid-packages collectively estimated value US\$ 5.1 million. Altogether, China's aid-support for Sudan estimated value nearly US\$ 11 million, moreover, only to construct the new presidency building, it made available interests-free credit estimated value US\$ 13 million (Herman, 2014). During years 2000 and 2014, China's banking, suppliers, besides government loans were up to US\$ 86 billion for Africa, and Sudan was in priority receiver (Alessi \& Xu, 2017). Moreover, through proportional 
point of view China's human-assistance aid-packages for Sudan are dominated by China's politicoeconomic engagement support for sub-structural developments and improvements. Evident, to mention that Sudan's crude-oil capital resources have provided politico-economic intensification which has principally beneficial for the states' fluvial selected community. Hence, provided foundation for recent demonstration, to expel an extended authoritative regime and demand for socio-political and socio-economic changeover in the state.

Beyond oil capital interests and diplomatic policies, nearby have been few variations into the natural resources excavation and production sectors in Sudan. China has most well-known contribution in energy venture like 'El-Gaili' power-plant; moreover, the most significant the contentious 'Meroe-dam' on great river Nile (Bosshard, 2011). Moreover, two of Chinese corporations are in to the construction and development of estimated US $\$ 1.5$ billion railwaytracks connecting Port Sudan to capital city Khartoum, hence started but, in continues improvements (Srinivasan, 2008). Furthermore, during last visit of Chinese president visit to Sudan, approved on a succession of a socio-economic and socio-political agreements with Khartoum; hence announced interests free-debits to construct different sectors including health and education sectors (Xinhua, 2018). Sudan's financial system is on the rise at nearly ten percentages and greatly of these owe to its association with China. On other hand, the credits, improved contest for supplies has enhanced the costs remunerated to manufacturers. China's ambassadorial approach towards the politico-economic instable conditions, more specifically the recent developments caused by demonstrators and coup d'état, have been observed at a very unusual stage of its participation in Sudan as well as the Africa. Moreover, the recent ambassadorial activities and politico-economic engagements would advocate the future dynamics of Sino-Sudan relations. Moreover, these demonstrations and change has been viewed as re-entry of west in general and US by the academia and analysts on the subject through developing responses.

\subsection{Challenges and Responses}

Currently, the China is facing assets' security challenge, where more recently the Beijing has been viewing apprehensions that UN involvement lacking the approval of Sudanese could cause warnings to handle with Africa at large. China's developments in African continent have been on its strategy of 'non-interference.' However, the policy has concerned central line-up of progression in western political views and complex issues. With the exception of this, domestic politico-economic instability and more particularly the recent developments under civilian demonstrations and military coup in Sudan to China's safety of interests too have worn-out China's policy of 'non-intervention' (Hodzi, 2018). However, China's management stresses its productive character addressing Darfur crisis prior to President Hu Jintao's 2007 visit to Sudan; marked the significance of peace and security for overall development in Sudan, therefore providing means to the transform that was improbable (McDoom, 2007). Hence, China's pressure on hybrid mediation character and expansion as a tool to manage the rootcauses of crisis in Darfur and instability in Sudan does not vary, however, a transformation can be observed. Moreover, China's acknowledgment of significance of politico-economic development process can also bridge the widening gap with west.

\section{Conclusion}

The Chinese factor in the African continent has developed into an imperative politico-economic 
collaborator of Khartoum since 1990s, the year of expanded relationship to most recent politicoeconomic instability in current year. In-fact, the Sudan's growth rate reached up to $10 \%$, merely because of the major investments and engagement by the China in the country. Though, there are few indications of re-allocations; however, China stays persistent to reinforce its multifaceted politico-economic, diplomatic, and military considerations with Sudan. Today, Beijing appeared to be managing a corresponding role in its diplomatic engagement and its trade, industry and energy interests following the economic engagement factors. However, recent engagement of China in Sudan appeared more dynamic in nature and character for its political and economic engagements. Hence, their connotations are expected to be further influential, comparative to earlier practices, thus might rapidly consequent apprehension for international community in general and west in particular. Moreover, the actual trial of both the states is that how much further the bilateral reimbursements reach to the general public in Sudan, at large, more specifically the after-myth developments of recent politico-economic instability, attracting international communities within Sudan.

\section{References}

AFP. (2018, February 5). Sudan devalues pound to 30 against US dollar. Retrieved from news24: $\quad$ https://www.news24.com/Africa/News/sudan-devalues-pound-to-30against-us-dollar-20180205.

Ahmed, G. K. (2010). The Chinese Stance on Darfur Conflict. South Africa: The South African Institute of International Affairs (SAIIA).

Alessi, C., \& Xu, B. (2017). China in Africa. New York: Council on Foreign Relations.

API, T. E. (2018, December 31). Sudan Inflation Rate. Retrieved from Trading Economics. https://tradingeconomics.com/sudan/exports/china/crude-oil-petroleum-bituminousminerals.

BBC. (2019, April 12). Africa: Sudan Coup-Military warns against disturbances. Retrieved from BBC News. https://www.bbc.com/news/world-africa-47908785.

BBC. (2019, April 22). Sudan crisis: Military issue protest warning. Retrieved from BBC News. https://www.bbc.com/news/world-africa-48006015.

Bosshard, P. (2011, January 20). New Chinese Dam Project Fuels Ethnic Conflict in Sudan. Retrieved from International Rivers. https://www.internationalrivers.org/blogs/227/new-chinese-dam-project-fuelsethnic-conflict-in-sudan.

Bramall, C. (2008). Chinese Economic Development. London: Routledge.

Brautigam, D. (2011). The Dragon's Gift: The Real Story of China in Africa. Oxford, UK: Oxford University Press.

Brosché, J. (2008). Darfur - Dimensions and Dilemmas of a Complex Situation. Uppsala University, Department of Peace and Conflict Research. Sweden: University Ckeriet, Uppsala.

Burke, J. (2019, April 11). Africa: Sudan's army to make statement as anti-Bashir protesters celebrate. Retrieved from The Guardian. https://www.theguardian.com/world/2019/apr/11/sudan-omar-al-bashir-protestscould-descend-chaos-anarchy-collapse-law-order-experts-warn.

CEIC. (2018, December). Sudan Total Exports. Retrieved from CEIC Data. https://www.ceicdata.com/en/indicator/sudan/total-imports. 
CNN. (2019, April 11). Sudan's Omar al-Bashir forced out in coup. Retrieved from CNN News: https://edition.cnn.com/africa/live-news/sudan-latest-updates/index.html

Coning, C. d., Aoi, C., \& Karlsrud, J. (2017). UN Peacekeeping Doctrine in a New Era. Milton Park, UK: Taylor \& Francis.

Currier, C. L., \& Dorraj, M. (2011). China's Energy Relations with the Developing World. Edinburgh, UK: A\&C Black Company.

Gill, B., \& Huang, C. H. (2009). China's expanding peacekeeping role: its significance and the policy implications. Solna, Sweden: SIPRI.

GNPOC. (2019, April 26). Mission Statement. Retrieved from Greater Nile Petroleum Operating Company Limited (GNPOC): http://www.gnpoc.com/Pages/missionstatement.aspx.

Goldstein, J. (2019, April 20). Africa: The Revolutionary Force Behind Sudan's Protest Movement? Doctors. Retrieved from The New York Times; https://www.nytimes.com/2019/04/20/world/africa/sudan-doctors-protest.html

Hammond, J. (2017, June 14). Sudan: China's Original Foothold in Africa. Retrieved from The Diplomat; https://thediplomat.com/2017/06/sudan-chinas-original-foothold-inafrica/

Herman, F. (2014). The Role and Influence of Chinese Bureaucrats Towards Peacekeeping Decision Making in the United Nations Mission in Darfur (Unamid): 2005 to 2012. International Journal of Multidisciplinary Academic Research, 2 (2), 9-22.

Hodzi, O. (2018). The End of China's Non-Intervention Policy in Africa. New York, US: Springer International Publishing.

IMF. (2017). Sudan: Staff Report; And Statement by The Executive Director for Sudan. Washington, DC: International Monetary Fund.

Khatoon, A., Rahim, N. \& Ali, B. (2018). A historical perspective of China's peaceful policies and its rise as world economic power. Liberal Arts and Social Sciences International Journal (LASSIJ), 2(1), 65-74.

Lai, H. H. (2007). China's oil diplomacy. Third World Quarterly, 28 (3), 519-735.

Large, D. (2009). China's Sudan Engagement: Changing Northern and Southern Political Trajectories in Peace and War. The China Quarterly, 610-626.

Larkin, B. D. (1973). China and Africa 1949-1970: The Foreign Policy of the People's Republic of China. California: University of California Press.

LeRiche, M., \& Arnold, M. (2013). South Sudan: From Revolution to Independence. Oxford, UK: Oxford University Press.

Lynch, J., Gramer, R., Lynch, C., \& O'donnell, J. (2019, April 11). In Sudan, a Transition to Democracy or a Military Power Play? Retrieved from Foreign Policy; https://foreignpolicy.com/2019/04/11/in-sudan-a-transition-to-democracy-or-amilitary-power-play-protests-omar-bashir-toppled-ousted-what-comes-nextkhartoum-east-africa-transition-movement/

Maglad, N. E. (2007). Impact of China and India on Sub-Saharan Africa: Scoping Studies on China-Africa Economic Relations. Tanzania: AERC in Dar es Salaam.

Manyok, P. (2016). Oil and Darfur's Blood: China's Thirst for Sudan's Oil. Journal of Political Sciences \& Public Affairs, 4 (1), 1-5.

McDoom, O. (2007, February 2). China's Hu visits Sudan: Presses on Darfur. Retrieved from Reuters, World News: https://www.reuters.com/article/us-africa-china/chinas-huvisits-sudan-presses-on-darfur-idUSL0213742620070202 
Omer, R. (2018, December 3). What is behind the economic and political crisis in Sudan? Retrieved from Africa is a Country: https://africasacountry.com/2018/03/current$\underline{\text { sudan-crisis }}$

Patey, L. A. (2011). Troubles in an African Oil Paradise. In D. Large, \& L. A. Patey, Sudan Looks East: China, India \& the Politics of Asian Alternatives (pp. 87-101). Woodbridge, UK: Boydell \& Brewer Ltd.

Powanga, L., \& Reichl, I. G. (2019). China's Contribution to the African Power Sector: Policy Implications for African Countries. Journal of Energy, 10.

Rehman, A. U., Hakim, A., Khan, K., \& Khan, I. U. (2018). Role of CPEC in development of trade, transport and Economy of Pakistan. Romanian Journal of Transport Infrastructure 7(1), 77-92.

Reuters. (2019, March 9). On International Women's Day, Sudan's Bashir orders release of female detainees. Retrieved from Egypt Today: http://www.egypttoday.com/Article/1/66829/On-International-Women-s-DaySudan-s-Bashir-orders-release

Shakeel, M. (2019, April 10). Africa: Sudan opposition says 20 killed since rally at army HQ held. Retrieved from Business Recorder: https://www.brecorder.com/2019/04/10/487676/sudan-opposition-says-20-killedsince-rally-at-army-hq-held/

Shay, S. (2005). The Red Sea Terror Triangle ( $1^{\text {st }}$ ed.). New York, USA: Routledge.

Speight, J. G. (2011). An Introduction to Petroleum Technology, Economics, and Politics. New Jersey, US: John Wiley \& Sons.

Srinivasan, S. (2008). A marriage less convenient: China, Sudan, and Darfur. In K. Ampiah, \& S. Naidu, Crouching Tiger, Hidden Dragon?: Africa and China (p. 357). New York, US: University of KwaZulu-Natal Press.

Taylor, I., \& Wu, Z. (2013). China's Arms Transfers to Africa and Political Violence. Terrorism and Political Violence, 25 (3), 457-475.

Tu, K. J. (2008, June 6). China Brief. Retrieved from The Jamestown Foundation: https://jamestown.org/program/smoke-and-mirrors-in-chinas-oil-statistics/

UNCTAD. (2018). World Investment Report 2018. Geneva: UN Publication.

VOA. (2019, April 9). Africa: US, Britain, Norway Demand 'Political Transition' Plan in Sudan. Retrieved from VOA News: https://www.voanews.com/a/us-britain-norwaydemand-political-transition-plan-in-sudan/4868303.html

WB. (2017). Sudan Exports by Region 2017. Retrieved, The World Integrated Trade Solution: https://wits.worldbank.org/CountryProfile/en/Country/SUD/Year/2017/TradeFlow/ Export/Partner/by-region

Woodward, P. (2013). Politics and Oil in Sudan. In D. K. Omeje, Extractive Economies and Conflicts in the Global South (pp. 107-134). Farnham, UK: Ashgate Publishing, Ltd.

World Bank. (2019, April 2). Sudan: Overview. Retrieved from The World Bank in Sudan: https://www.worldbank.org/en/country/sudan/overview

Xinhua. (2018, September 2). Xi meets Sudanese president. Retrieved from Xinhua News: http://www.xinhuanet.com/english/2018-09/02/c_137438661.htm 